\title{
ANALISIS PERGESERAN KEGIATAN EKONOMI JAWA TIMUR MELALUI PENGUATAN KEARIFAN LOKAL
}

\section{Setyo Wahyu Sulistyono}

Ekonomi Pembangunan, Fakultas Ekonomi dan Bisnis, Universitas Muhammadiyah Malang, Indonesia

Corresponding author: setyowahyu88@umm.ac.id

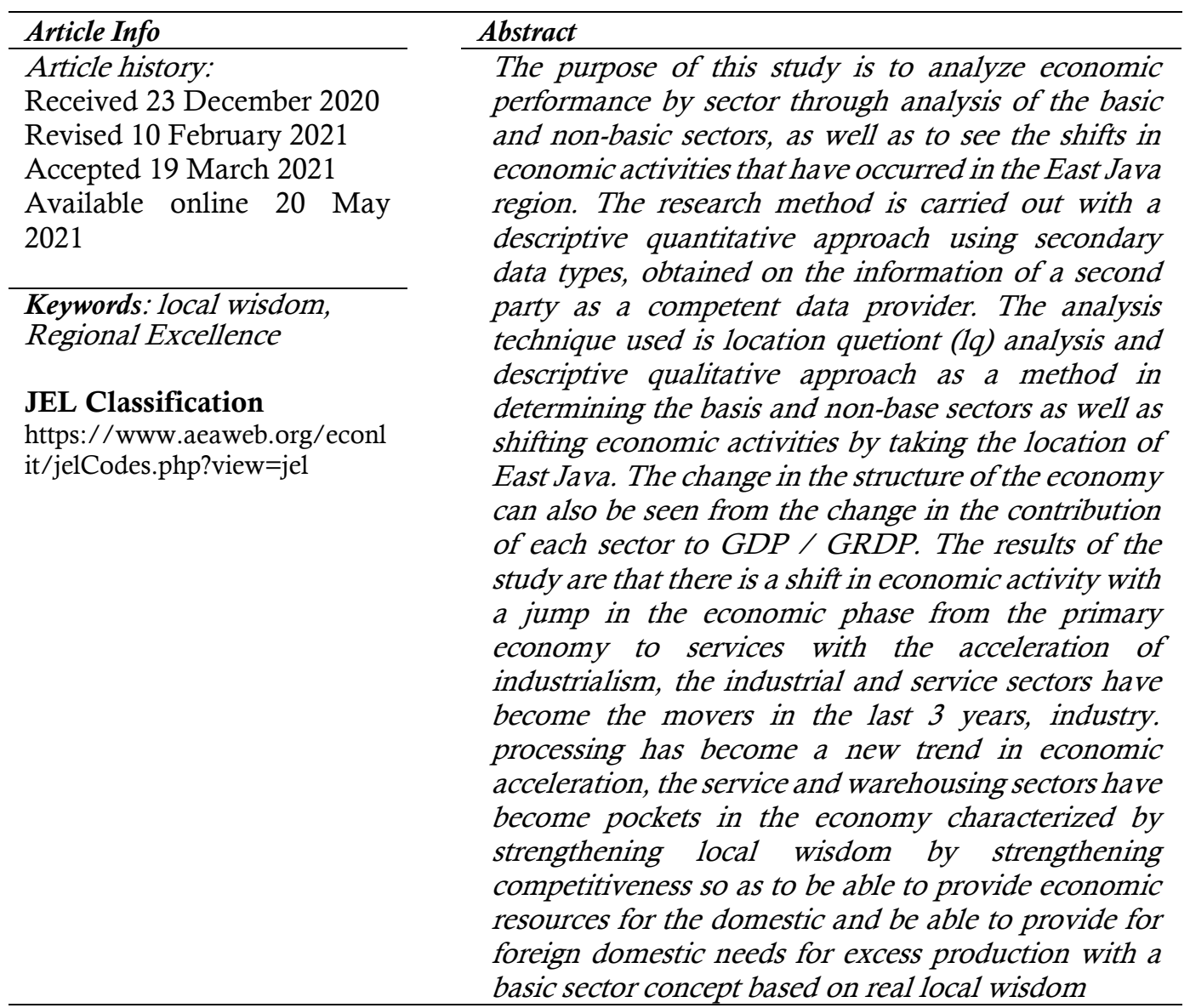

\section{PENDAHULUAN}

Pembangunan yang seutuhnya mengarah pada bentuk kesejahteraaan masyarakat yang seutuhnya atas helicopter views yang dilihat atas kemampuan masyarakat berkontribusi melalui kegiatan ekonomi atas setiap unitnya yang terakumulasi menjadi suatu bagian yang utuh. Mengutip dari pemahaman ekonomi klasik, bentuk pembangunan tidak seutuhnya dilihat dari susunan maupun tatanan angka yang tercermin melalui refleksi atas GNP dalam mengungkapkan bentuk dari state of mind dalam kondisi masyarakat yang sebenarnya diakibatkan beberapa decade menyajikan bentuk jurang pemisah polarisasi dengan semakin pesatnya pertumbuhan sehingga sering terjadi kondisi Margin of error yang begitu terlihat yang memberikan ruang yang begitu sempit dalam memilih 
alternative solusi pembangunan, kecuali dengan mengesampingkan aspekaspek sosial budaya dan kehidupan bermasyarakat atas tindakan para pelaku ekonomi.

Oleh sebab itu pembangunann dapat dikatakan sebagai bentuk kombinasi yang diungkapkan secara multidimensional yang meliputi perubahan dan pergeseran dalam struktur ekonomi, sosial dan budaya. Bentuk dari capayan kesejahteraaan dilakukan secara long run maupun short run. Dengan pemikiran pencapaian hanya mencapai pada kebutuhan pokok dalam lingkup individu saja atau kebutuhan dalam pemikiran kemampuan memenuhi kebutuhan diluar individu. Pemikiran ekonomi berkelanjutan menjadi salah satu capaian tujuan jangka paanjang dalam kondisi ekonomi pencapaian yang bertumpu pada aktifitas masyarakat.

Menurut Ahossene dalam (Mukhlis, 2009) bentuk dari ekonomi keberlanjutan yang harus dipenuhi, yakni;

1. Integrasi lingkungan dalam proses pembangunan ekonomi.

2. Pemerataan.

3. Distribusi terhadap pengaruh kekuatan dan ekonomi.

4. Berorientasi pada masa depan

Kegiatan antisipasi harus tersedia lebih dulu dari pada kegiatan reaksi. aktifitas ekonomi secara sektoral dengan penyerapan pekerjaan sebagai bentuk kegiatan aktifitas masyarakat yang terfokuskan pada pembagian tugas dan fugsi di dalam kontribusi barang dan jasa penyedia bagi diri sendiri maupun masyarakat lainnya sebagai akumulasi di wilayah tertentu, yang setiap periodenya mengalami penguatan dan pergeseran aktifitas ekonomi melalui kinerja sektoral. selanjutnya bentuk pergeseran tersebut menarik untuk dikaji dalam satuan kewilayahan keresidenan Jawa Timur ekonomi dengan karakteristik kawasan homogen dengan konteks sejenis. oleh sebab itu penulis menilai pentingnya penelitian tersebut sebagai upaya membaca situasi yang terjadi atas kondisi analisis pergeseran kegiatan ekonomi melalui penilaian kinerja secara sektoral di wilayah Jawa Timur dengan menitik beratkan pada aktifitas masyarakat melalui penguatan kearifan local

Bentuk dari Tujuan pembangunan ekonomi dalam suatu wilayah pada umumnya menurut (Suparmoko, 2002) adalah peningkatan pendapatan rill perkapita serta adanya unsur keadilan atau pemerataan dalam penghasilan dan kesempatan dalam kontribusi kegiatan ekonomi yang dilihat dari aktifitas ekonomi masyarakat dalam setiap inividu. Dengan mengetahui secara seksama bentuk arah tujuan dan sasaran pembangunan dalam periode tertentu, serta kekuatan dan kelemahan yang di miliki suatu daerah, maka strategi pengembangan potensi yang ada akan lebih terarah dan strategi tersebut akan menjadi pedoman bagi pemerintah daerah atau siapa saja yang akan melaksanakan kegiatan usaha di daerah yang bersangkutan dengan bentuk penekanan bertumpu pada aktifitas ekonomi masyarakat secara mendalam. 
Oleh karena itu, dalam mempersiapkan strategi pengembangan potensi yang ada di daerah, langkah-langkah yang dapat di tempuh sebagai berikut :

Mengidentifikasi sektor-sektor kegiatan ekonomi secara basis dan non basis sebagai dasar penentuan kemampuan ekonomi dalam wilayah tertentu

1. Mengidentifikasi sektor-sektor yang potensinya rendah untuk di kembangkan dan mencari faktor-faktor yang menyebabkan rendahnya potensi sektor tersebut untuk di kembangkan.

2. Selanjutnya mengidentifikasi sumber daya (faktor-faktor produksi) yang ada termasuk sumber daya manusianya dan yang siap untuk di gunakan untuk mendukung perkembangan setiap sektor yang saling bersangkutan.

3. Dengan menggunakan model pembobotan terhadap variabel-variabel kekuatan dan kelemahan untuk setiap sektor dan sub sektor, maka akan di temukan sektorsektor andalan yang selanjutnya di anggap sebagai potensi ekonomi yang patut di kembangkan di daerah yang bersangkutan.

4. Akhirnya menentukan strategi yang akan di tempuh untuk pengembangan sektorsektor andalan yang akan dapat menarik sektor-sektor lain untuk tumbuh sehingga perekonomian akan dapat berkembang dengan sendirinya (self propelling) secara berkelanjutan (sustainable development).

\section{Teori Sektor Unggulan}

Perkembangan Potensi Ekonomi Daerah Potensi ekonomi suatu wilayah dapat dilihat dari kapasitas kemampuan pertumbuhan output/produksi jika dibandingkan dengan kapasitas perekonomian sekitarnya, misalnya saja perekonomian nasional. Jika suatu daerah mengalami pertumbuhan ekonomi di bawah pertumbuhan ekonomi nasional, berarti kapasitas pertumbuhan ekonomi belum tercapai secara optimal

Menurut Deptan dalam (Hajeri, Yurisinthae, \& Dolorosa, 2015) Sektor unggulan perekonomian adalah sektor yang memiliki ketangguhan dan kemampuan tinggi sehingga dapat dijadikan sebagai tumpuan harapan pembangunan ekonomi. Sektor unggulan merupakan tulang punggung dan penggerak perekonomian, sehingga dapat juga disebut sebagai sektor kunci atau sektor pemimpin perekonomian suatu wilayah. Dengan demikian, sektor unggulan merupakan refleksi dari suatu struktur perekonomian, sehingga dapat pula dipandang sebagai salah satu aspek penciri atau karakteristik dari suatu perekonomian.

Proses dari pembangunan wilayah sebaiknya lebih mengarah dan menekankan serta memperhatikan bentuk dari keunggulan dan 
karakteristik dari setiap daerah yang tercermin melalui kegiatan secara sektoral sebagai angka akumulatif atas kegiatan persetiap individu masyarakatnya. Berbagai hasil dari perkembangan dan pertumbuhan sektor ekonomi di suatu daerah inilah menjadi penguat bagi daerah tersebut secara dominan, maka daerah akan memiliki berbagai keuntungan yang dapat diserap dalam rangka proses pelaksanaan kekuatan yang mampu diunggulkan.

\section{Teori Basis Ekonomi}

Teori basis ekonomi ini dikemukakan oleh (Harry W. Richardson. 1973) yang menyatakan bahwa faktor penentu utama pertumbuhan ekonomi suatu daerah adalah berhubungan langsung dengan permintaan akan barang dan jasa dari luar daerah. Dalam teori basis ekonomi (economic base) bahwa semua wilayah merupakan sebuah sistem sosio ekonomi yang terpadu. Teori inilah yang mendasari pemikiran teknik location quotient, yaitu teknik yang membantu dalam menentukan kapasitas ekspor perekonomian daerah dan derajat keswasembada (Selfsufficiency) suatu sektor.

Menurut (Glasson. 1990) konsep dasar basis ekonomi membagi perekonomian menjadi dua sektor yaitu:

a. Sektor-sektor basis adalah sektor-sektor yang mengekspor barangbarang dan jasa ke tempat di luar batas perekonomian masyarakat yang bersangkutan.

b. Sektor-sektor bukan basis adalah sektor-sektoryang menjadikan barang- barang yang dibutuhkan oleh orang yang bertempat tinggal di dalam batas perekonomian masyarakat bersangkutan.

\section{Penguatan Ekonomi Berlandaskan Kearifan Lokal}

Bentuk penguatan atas kegiatan sektoral mengarah pada kemampuan dalaam setiap wilayah atas kekuatan potensi yang dimiliki akibat given berupa topografi dan Kekayaan berlandaskan kekuatan spasial bentuk lain menyebutkan kearifan lokal adalah pengetahuan dan cara berpikir dalam kebudayaan kelompok manusia yang terukur di dalam tatanan masyarakat dan berprilaku ekonomi demi pencapaian kesimbangan atas permintaan dan penawaran, yang merupakan basil dari pengamatan kurun waktu yang lama, Kearifan berisi suatu pandangan hidup masyarakat berkaitan tentang struktur lingkungan, bagaimana lingkungan berfungsi, bagaimana reaksi alam atas tindalcan manusia, dan hubungan timbal balik antara manusia dengan lingkungannya.

Bentuk stimulus dalam menggali kearifan lokal sebagai isu sentral secara umum dan tersktuktur adalah untuk mencari pengakuan akan kekuatan secara regional, jika dikehendaki, menetapkan identitas spasial, yang mungkin hilang karena proses persilangan dialektis seperti 
dikemukakan atas proses koloaborasi yang mengacu pada kekuatan daya saing satu daerah dengan daerah lainnya, atau karena akulturasi dan transformasi yang telah, sedang, dan akan terus terjadi sebagai sesuatu yang tak terelakkan.

Perlunya penguatan kearifan lokak berdasarkan sektoral berangkat atas identitas yang nantinya jadi alasan kuat akan kegiatan ekonomi masyarakat yang mampu terukur dan dikelompokan dalam satu kesamaan lingkungan berekonomi dengan cara bertindak dan berprilaku dalam pasar

\section{METODE PENELITIAN}

\section{Lokasi Penelitian}

Penelitian ini mengambil lokasi di Kawasan Jawa Timur merupakan bentuk dari pendistribusian barang dan jasa bentuk mobilitas manusia sebagai mesin penggerak ekonomi yang menjadi populasi dan sampel dalam penelitian ini

\section{Ruang Lingkup Penelitian}

Untuk mendapatkan pemetaan komoditas unggulan yang dominan dari yang berada di Kawasan Jawa timur, maka diperlukan beberapa tahapan analisis. Berikut tahapan analisis yang dilakukan yaitu :

1. Analisis Location Quotient (LQ) digunakan untuk menentukan sektor basis dan non basis dalam perekonomian wilayah Kota Kawasan Jawa Timur

2. Pendekatan secara Kualitatif, Penelitian ini dilaksanakan di wilayah administrasi yang terletak di Kawasan Jawa Timur. Analisis data dilakukan menggunakan metode deskriptif kualitatif. Analisis kualitatif adalah suatu metode untuk menelaah mengenai esensi, mencari makna dibalik frekuensi dan variasi (Yunus, 2010). Data dianalisis secara deskriptif kualitatif dengan menginterpretasikan fakta yang ditemukan di lapangan. Data yang dikumpulkan terdiri dari data sekunder yaitu

kegiatan ekonomi lokal Kawasan Jawa Timur atas penelitian rujukan sebelumnya. Data dikumpulkan dengan menggunakan dokumentasi dan observasi

\section{Tahapan Pelaksanaan Analisis}

\section{Analisis Location Quotient (LQ)}

Analisis Location Quotient di gunakan karena memiliki kebaikan berupa alat analisis yang sederhana yang dapat menunjukkan struktrur perekonomian suatu daerah dan industri substitusi impor potensial atau produk yang bisa dikembangkan untuk ekspor dan menunjukkan industri potensial untuk di analisis lebih lanjut.Alat analisis Location Quetiont dimaksudkan untuk mengidentifikasi dan merumuskan komposisi dan pergeseran sektor basis suatu wilayah dengan menggunakan data Produk Domestik Regional Bruto (PDRB) sebagai indikator pertumbuhan wilayah 
Secara sistematis perhitungan LQ dinyatakan sebagai berikut:

$$
\mathrm{LO}=\frac{\mathrm{si} / \mathrm{s}}{\mathrm{Ni} / \mathrm{n}}
$$

$\mathrm{L}$

Keterangan: $\mathrm{LQ}=$ Nilai Location

Quotient (LQ). Si = PDRB sektor i di Kota

studi

$$
\mathrm{S}=\text { PDRB total di Kota studi }
$$

$\mathrm{Ni}=\mathrm{PDRB}$ sektor $\mathrm{i}$

diProvinsi Jawa Timur N = PDRB

total di Provinsi Jawa Timur

Jika hasil perhitungannya menunjukkan LQ $>1$, berarti tingkat spesialisasi sektor i di Kota studi lebih besar di banding sektor yang sama pada Provinsi Jawa Timur berarti merupakan sektor basis dan berpotensi untuk ekspor, sedangkan LQ

$<1$, berarti tingkat spesialisasi sektor i di Kota studi lebih kecil di banding sektor yang sama pada Jawa Timur berarti bukan sektor basis (sektor lokal/impor). Bila LQ=1 berarti tingkat spesialisasi sektor i di Kota studi sama dengan sektor yang sama pada Provinsi Jawa Timur.

\section{Kajian deskriptif kualitatif}

Analisis kualitatif adalah suatu metode untuk menelaah mengenai esensi, mencari makna dibalik frekuensi dan variasi (Yunus, 2010). Data dianalisis secara deskriptif kualitatif dengan menginterpretasikan fakta yang ditemukan di lapangan. Data yang dikumpulkan terdiri dari data sekunder yaitu kegiatan ekonomi lokal Kawasan Jawa Timur atas penelitian rujukan sebelumnya. Data dikumpulkan dengan menggunakan dokumentasi dan observasi melalui kegiatan penelitian sebelumnya

\section{HASIL DAN PEMBAHASAN}

\section{Karakteristik Tenaga Kerja}

Penyerapan tenaga kerja industry manufaktur menjadi menarik ketika pada sector tersebut dapat menyerap tenaga kerja dengan kapasitas yang besar sebagai pendorong dalam perekonomian sehingga mampu menjadi sector superior di dalam penguatan ekonomi kewilayahan, penyerapan tenaga kerja dari jumlah tenaga kerja yang dapat diserap, peran sektor industri manufaktur dalam menyerap tenaga kerja nasional memang masih relatif rendah. Distribusi penyerapan tenaga kerja masih terkonsentrasi pada sektor pertanian sebesar (41\%) dan sektor jasa seperti perdagangan $(21 \%)$, pengangkutan $(6 \%)$ dan jasa- jasa lain $(12 \%)$. Bentuk fenomenalogi inilah yang mengarah pada pergeseran penyerapan tenaga kerja dan aktifitas ekonomi yang mengarah pada sector industry dengan menitik beratkan atas aktifitas masyarakat berdasarkan kemampuan dan 
kualitas Sumber Daya Manusia (SDM), momentum Ketika aktifitas masyarakat merupakan akumulatif atas aktifitas regional Jawa Timur melalui helicopter View inilah momentum disebut kearifan local indutrialisme dengan mengarah pada aktifitas masyarat sebagai subjek dalam kegiatan ekonomi sectoral, dengan ikut serta masyarakat dalam proses roda ekonomi menekankan pada tatanan struktur kesejahteraan hal tersebut didung oleh penelitian Ikka Dewi (2013) mengenai pengaruh investasi dan tingkat upah terhadap kesempatan kerja di Jawa Timur menemukan bahwa tingkat upah berpengaruh signifikan terhadap kesempatan kerja, dalam pendekatan ini daya dukung tenaga kerja dalam penggerak ekonomi khususnya Indonesia dengan bonus demograsi menjadi peluang yang besar atas percepatan ekonomi pertumbuan yang terstruktur

\section{Karakteristik Industri Jawa Timur}

Penyerapan tenaga kerja di sector industri Jawa Timur mampu menyerap sebesar 22,32 \% walaupun sector industry dianggap sebagai sector superior namun dalam penyerapan tenaga kerja di sector industry masih belum dapat melampaui penyerapan pada sector pertanian, dengan berbagai kriteria atas ketersediaan lapangan pekerjaan di Jawa Timur sector industry dan kualifikasi dalam penyerapan tenaga kerja menjadi permasalahan tersendiri.

Perjalanan tahun mengungkap ketersediaan industry di Jawa Timur mengalami peningkatan perubahan skema dan sectoral menjadi hal mendorong penguatan fundamental ekonomi melalui pola distribusi berbasis industrialis, pemerintah menangkap peluang atas berkemajuannya sectoral secara sekunder dengan infrastruktur yang sangat menunjang bagi keberadaan pertumbuhan industry di Jawa Timur, dari tabel berikut dapat dinilai bentuk penyerapan aktifitas industry Jawa Timur mengalami peningkatan secara bertahap dengan penaikan secara signifikan atas nilai tahun 2000 hingga 2014 dengan percepatan Apabila dilihat dari jenis industrinya, Industri Pakaian Jadi, Tekstil, Makanan dan Minuman, serta Furnitur merupakan industri yang mampu menjadi pergerakan roda perekonomian di jawa timur

Tabel 4

Jumlah Industri Jawa Timur

\begin{tabular}{rr}
\hline \multicolumn{2}{c}{ INDUSTRI JAWA } \\
Tahun & TIMUR \\
\hline 2001 & 625082 \\
2002 & 626808
\end{tabular}




\begin{tabular}{ll}
2003 & 642848 \\
2004 & 653859 \\
2005 & 661720 \\
2006 & 671681 \\
2007 & 680242 \\
2008 & 689736 \\
2009 & 716441 \\
2010 & 742671 \\
2011 & 783955 \\
2012 & 795410 \\
2013 & 803453 \\
2014 & 807478 \\
2015 & 811273 \\
2016 & 813140 \\
2017 & 814848 \\
2018 & 816804 \\
2019 & 834822 \\
\hline
\end{tabular}

\section{Sumber : Diolah 2019}

Dengan ketersediaan jumlah industry yang mengalami peningkatan sangat terkait dengan pembahasan di atas terkait tenaga kerja. Menurut teori yang dikemukakan oleh Harrod Domar bahwa kenaikkan tingkat output dan kesempatan kerja dapat dilakukan dengan adanya akumulasi modal (investasi) dan tabungan, namun teori tersebut tidak sesuai dengan kasus dalam penelitian ini. Tidak adanya pengaruh investasi terhadap penyerapan tenaga kerja dimungkinkan karena para pemilik usaha dalam menggunakan investasinya lebih cenderung untuk melakukan pembelian barang modal dalam bentuk mesin-mesin sebagai pendukung proses produksi perusahaan yang bertujuan untuk memperbaiki kualitas produksi dan meningkatkan produktivitas dari barang dan jasa yang lebih efektif dan efisien

\section{Pergeseran Aktifitas Ekonomi}

Kegiatan ekonom sektorali dalam proses upaya peningkatan pertumbuhan ekonmi sebagai indikator perubahan struktur perekonomian, transformasi structural mengalami perjalanan fase dari perekonomian primer, sekunder dan tersier. Perekonomian dengan skema primer dilihat melalui aktifitas menitik beratkan pada pertanian, perekonomian sekunder dengan titik tumpu pada sector perdagangan dan sector jasa sebagai penguatan ekonomi secara tersier. Atas altifitas stersebut seluruh sumber daya factor produksi akan mengalami peningkatan nilai tambah atas keterkaitan keseimbangan ekonomi pasar seperti paradigma keseimbangan 
mandiri komposisi jumlah permintan, penawaran, aktifitas perdagangan, produksi dan factor lainnya.

Menurut Chenery dalam pemikirannya kegiatan pergeseran aktifitas ekonomi merupakan hal yang sangat alamiah, yang sedang dilakukan atas suatu konsekuensi perekonomian yang sedang tumbuh, dan peran pemerintah dalam scenario percepatan pembangunan sangatlah ideal dimomentum pergeseran transformasi yang memiliki nilai positif Bentuk pergeseran ekonomi sejalan dengan penyerapan tenaga kerja di tengah tengah menjamurnya industrialism, dalam hal ini pemerintah melalu kebijakan yang proaktif dan agresif menjadi penguat dan daya dukung, Jawa Timur dalam hal ini berhasil ditujukkan bahwa tingkat pertumbuhan ekonomi dan peranan suatu sektor dalam menciptakan produksi nasional tergantung pada tingkat pendapatan dan jumlah penduduk, dimana Jawa Timur sebagi arus barang dan jasa mampu mengarah pada penguatan aktifitas masyarakat dengan penyesuaian atas tumpuan dari kearifan lokal. Makin besar pertumbuhan pendapatan suatu daerah dibanding dengan pertumbuhan penduduk daerah tersebut maka dikatakan bahwa pertumbuhan ekonomi meningkat. Terjadinya perubahan struktur ekonomi ini juga dapat dilihat dari perubahan kontribusi setiap sektor terhadap PDB/PDRBnya, Tabel di atas menunjukan pergeseran aktifitas ekonomi dengan loncatan fase ekonomi dari ekonomi primer beranjak ke jasa dengan percepatan industrialism, sector industry dan jasa menjadi penggerak di 3 periode tahun terakhir, industry pengolahan menjadi trend baru dalam percepatan ekonomi, sector jasa dan pergudangan menjadi kantong kantong dalam perkonomian dengan ciri penguatan atas kearifan lokak degan penguatan daya saing sehinga mampu menyediakan sumber daya ekonomi untuk domestic dan mampu menyediakan atas kebutuhan luar domestic atas kelebihan produksi dengan konsep sector basis berlandaskan kearifan local yang sesungguhnya

\section{KESIMPULAN DAN SARAN [Calisto MT - 12 - bold]}

\section{Kesimpulan}

Kesimpulan umum dalam penelitian ini adalah bahwa pengaruh perubahan struktur ekonomi berpengaruh terhadap fungsi spesialisasi dan struktur penyerapan tenaga kerja sektoral untuk daerah perkotaan di Jawa Timur atas ketersediaan industry, melalui aktifitas industry terjadi penguatan dalam aktifitas ekonomi masyarakat mendorong kesejahteraan. Perubahan struktur ekonomi terjadi atas perjalanan tiga tahun terakhir dengan percepatan melalui dorongan kebijakan Publik Jawa Timur menjadikan pergeseran ekonomi menuju fase ekonomi tersier menitik beratkan pada sector jasa, penyerapan tenaga kerja mengalami perubahan dimana sector pertanian yang dianggap mampu menyerap dengan jumlah 
tenaga kerja yang besar mengalami transformasi ke sector perdagangan dan industri yang dianggap lebih efektif dalam percepatan pergerakan ekonomi. Selanjutnya pergeseran aktifitas ekonomi dengan loncatan fase ekonomi dari ekonomi primer beranjak ke jasa dengan percepatan industrialism, sector industry dan jasa menjadi penggerak di 3 periode tahun terakhir, industry pengolahan menjadi trend baru dalam percepatan ekonomi, sector jasa dan pergudangan menjadi kantong kantong dalam perkonomian dengan ciri penguatan atas kearifan lokak degan penguatan daya saing sehinga mampu menyediakan sumber daya ekonomi untuk domestic dan mampu menyediakan atas kebutuhan luar domestic atas kelebihan produksi dengan konsep sector basis berlandaskan kearifan local yang sesungguhnya

\section{Saran}

Perencanaan percepatan pembangunan berbasisi aktifitas ekonomi masyarakat dengan menitik beratkan masyarakat sevagai subjek pembangunan dengan melibatkan indstri dan jasa yang terintegrasi hendaknya segera dilaksanakan sebagai kesiapan menghadapi percepatan dimensi pembangunan dengan mengarah pada penguatan sector basis, agar disparitas pembangunan menjadi lebih kecil yang pada akhirnya akan menghasilkan pertumbuhan ekonomi yang tinggi. Untuk sektor tersier Pemerintah Daerah hendaknya memberikan bantuan /kemudahan untuk memperoleh permodalan bagi pengusaha menengah, kecil dan koperasi agar lebih mempercepat proses ditribusi pembentukan pendapatan antar golongan masyarakat.

\section{DAFTAR PUSTAKA [Calisto MT - 12 - bold]}

Glasson, John, 1990,Pengantar Perencanaan Re-gional, terjemahanPaul Sitohang, Jakarta: LPFEUI

Hajeri, H., Yurisinthae, E., \& Dolorosa, E. (2015). Analisis Penentuan Sektor Unggulan Perekonomian di Kabupaten Kubu Raya. Jurnal Ekonomi Bisnis Dan Kewirausahaan, 4(2), 253. https://doi.org/10.26418/jebik.v4i2.12485

Mukhlis, I. (2009). Eksternalitas, Pertumbuhan Ekonomi dan Pembangunan Berkelanjutan dalam Perspektif Teoritis. Jurnal Ekonomi Bisnis, 14(3), 191-199. Retrieved from http://fe.um.ac.id/wp-content/uploads/2010/01/imammukhlis_2.pdf.

Nuraini, I., Hidayat, R., \& Sulistyono, S. W. (2020). INTERACTION DETERMINING FACTORS FROM REGENCY/CITY REGION IN EAST JAVA. Jurnal Ekonomi 
Pembangunan, 17(2), 152-163.

Rahmawati, Ikka Dewi. 2013. Pengaruh Investasi dan Tingkat Upah Terhadap Penyerapan Tenaga Kerja di Jawa Timur. Skripsi. Universitas Negeri Surabaya

Sulistyono, S. W. (2018). ECONOMIC TYPOLOGY APPROACH TO CALCULATE UNEMPLOYMENT INDEX AND REGIONAL POVERTY RATE (STUDY IN TAPAL

KUDA AREA OF EAST JAVA). Jurnal Ekonomi Pembangunan, 16(2), 147-165. Sulistyono, S. W., Nur, I., \& Susilowati, D. (2018, October). DISPARITAS DAN POLA

KONSUMSI MASYARAKAT KOTA MALANG. In Seminar Nasional dan Call for Paper III Fakultas Ekonomi (pp. 421436).

Suliswanto, M. S. W., Sulistyono, S. W., Arifin, Z., \& Abdullah, M. F. (2019). Reflection of Indonesian Economic Development Model Approach Through the Economic and Social Dynamics Ibnu Khaldun.

Suparmoko M, 2002. "Ekonomi Publik untuk Keuangan \& Pembangunan Daerah. Penerbit Andi, Yogyakarta.

Yunus, Hadi Sabari. 2010. Metodologi Penelitian Wilayah Kontemporer. Yogyakarta: Pustaka Pelajar 